\title{
A Coluna Prestes e as relações Brasil-Argentina na década de 1920
}

\author{
Prestes Column and the \\ Brazilian-Argentine relations in the 1920s
}

DOI: $10.21530 /$ ci.v11n1.2016.261

Mateus Fernandez Xavier ${ }^{1}$

\section{Resumo}

O presente artigo tem como objetivo apontar as influências da Coluna Prestes sobre a política externa brasileira da década de 1920 para a Argentina. Por meio da análise do contexto político, social, econômico e internacional do país, foi possível compreender as condicionalidades impostas à atuação externa do Brasil. A apresentação da configuração do Exército Brasileiro e dos movimentos subversivos que tiveram origem no interior dessa instituição também forneceu elementos importantes para o estabelecimento da relação existente entre a Coluna Prestes e as medidas tomadas pelas chancelarias de Félix Pacheco e, em menor medida, de Otávio Mangabeira. Por meio da correlação de dados e informações levantados foi possível perceber como o Ministério das Relações Exteriores foi utilizado como instrumento de repressão a movimentos que contestaram a ordem oligárquica da República Velha.

Palavras-chave: Coluna Prestes; política externa brasileira; movimentos revolucionários; repressão; Ministério das Relações Exteriores; Argentina.

\section{Abstract}

This article attempts to describe the influences that the 'Coluna Prestes' had on the Brazilian foreign policy for Argentina during the 1920 decade. Analyzing the political, social, economic and international context of that period, it was possible to understand which limits of

1 Doutorando em Relações Internacionais pela Universidade de Brasília, possui mestrado em Relações Internacionais pela mesma instituição, mestrado em Diplomacia pelo Instituto Rio Branco (2011). Diplomata de carreira, trabalha atualmente em Brasília.

Artigo recebido em 16/10/2015 e aprovado em 23/02/2016. 
action affected Brazilian international movements. The description of the Brazilian Army configuration and the analysis of the insurgent revolutionary movements that were triggered by ideologies of this institution, furnish important information on the impacts of 'Coluna Prestes' over the chancelleries of Félix Pacheco and, to a lesser extent, of Otávio Mangabeira. Correlating all data obtained, it is possible to perceive how the Ministry of External Relations was used as an instrument of repression against the movements that opposed the oligarchic order of the República Velha.

Keywords: Coluna Prestes; Brazilian foreign policy; revolutionary uprisings; repression; Ministry of External Relations; Argentina.

\section{Introdução}

A existência de poucos estudos a respeito da política externa brasileira durante a década de 1920 e o fato de o governo Artur Bernardes ter sido caracterizado por grande agitação interna chamam atenção para os anos compreendidos entre 1922 e 1926. Nesse período, a Coluna Prestes destacou-se como movimento importante no contexto de grande agitação ideológica dentro das Forças Armadas brasileiras. Considerando que a marcha revolucionária de Isidoro Dias Lopes, Miguel Costa, Luiz Carlos Prestes, Siqueira Campos, Cordeiro de Farias, Juarez Távora e João Alberto passou por regiões próximas à fronteira do Brasil com a Argentina, atravessou território paraguaio para ingressar no Mato Grosso e exilou-se na Bolívia, é plausível concluir que esse movimento produziu impactos internacionais.

Com vistas a compreender como a política externa brasileira foi influenciada pela Coluna Prestes e pelos movimentos rebeldes que lhe originaram, é importante entender, previamente, a situação política, social e econômica do Brasil naqueles anos. A elucidação do contexto histórico da década de 1920 e das causas que deram origem à eclosão do movimento em questão proporciona suporte para compreender as principais ideologias que orientaram as Forças Armadas e os integrantes da Coluna Prestes, além de destacar as diretrizes essenciais que pautaram a política externa brasileira no período.

O presente artigo busca demonstrar como o movimento rebelde mencionado causou repercussão principalmente na América do Sul, com destaque para a Argentina. As missões diplomáticas do Brasil em Assunção, Buenos Aires, Montevidéu e La Paz enviaram informes, telegramas e outras correspondências diplomáticas com significativa frequência ao Rio de Janeiro, dando ciência ao 
governo federal das ações dos jovens oficiais. De acordo com o planejamento dos rebeldes, a busca por víveres, suprimentos e armamentos nos países vizinhos era essencial para a marcha, e o governo federal bem o sabia. Dessa maneira, durante o mandato de Artur Bernardes, a política externa brasileira para a região platina foi caracterizada por considerável esforço para neutralizar o empreendimento logístico da Coluna e amenizar as repercussões negativas advindas do combate aos insurgentes, gerando impactos expressivos sobre as relações bilaterais com a Argentina.

\section{As origens e o desenvolvimento da Coluna Prestes}

\section{O contexto doméstico e as ideologias em voga nas Forças Armadas}

Configurado por anos de grande instabilidade política e social, o período denominado pela historiografia brasileira de República Velha (1889-1930) abrangeu desde os governos militares de Deodoro da Fonseca (1889-91) e Floriano Peixoto (1891-94) até a Revolução de Trinta e a ascensão de Vargas ao poder. Ao longo desses anos, o país foi palco de diversas revoltas e sublevações de cunho militar, além de inúmeras contestações civis.

Entre 1889 e 1930, a sociedade brasileira tornou-se mais complexa e a crescente urbanização e industrialização do país fizeram surgir uma classe operária nas grandes cidades da época, composta, em sua maioria, por imigrantes europeus. Foi desta maneira que ideias anarquistas e socialistas chegaram a São Paulo e ao Rio de Janeiro, por exemplo, no início do século XX.

Além dos operários, as camadas médias urbanas foram outro setor da sociedade que se formou a partir dos processos de industrialização e urbanização. Esse conjunto de agentes nunca apresentou coesão em suas ações uma vez que era composto por grupos de diferentes interesses. Assim, filhos de famílias tradicionais decadentes, profissionais liberais, pequenos proprietários de fábricas, comerciantes, funcionários públicos e intelectuais faziam parte do crescente setor médio da sociedade e, com o tempo, passaram a reivindicar maior participação na vida política da nação (MENDONÇA, 1990, p. 320).

$\mathrm{O}$ equilíbrio de poder entre as oligarquias nacionais também foi alterado nesse período. Enquanto algumas oligarquias dissidentes, como a do Rio Grande do Sul e outras do Nordeste, iniciaram processo de fortalecimento, as tradicionais de Minas Gerais e São Paulo começaram a apresentar cisões. Essa conjuntura 
política caracterizada pela ascensão de novos protagonistas e pelo enfraquecimento de antigos grupos hegemônicos foi responsável pela crescente animosidade no Brasil, durante a década de 1920. Como consequência, o contexto político à época caracterizou-se pela insatisfação de setores da sociedade brasileira alijados do processo de decisão desde início do século: operários, camadas médias urbanas, forças armadas e crescente número de oligarquias dissidentes demandavam a implantação do voto secreto, a criação de uma justiça eleitoral, a disponibilização de educação pública obrigatória, a independência do Legislativo e do Judiciário em relação ao Executivo e maior moralidade política e administrativa no país (MENDONÇA, 1990, p. 318-319).

A eleição de Artur Bernardes para a Presidência, com apoio das oligarquias dominantes de Minas Gerais e São Paulo, contribui para melhor apreender o clima tenso vigente à época. Nilo Peçanha, candidato opositor lançado pela Reação Republicana, recebeu suporte de oligarquias dissidentes de Rio de Janeiro, Pernambuco, Bahia, Rio Grande do Sul e de grupos do Exército ligados a Hermes da Fonseca, como os jovens tenentes, por exemplo². Apesar da considerável quantidade de ameaças e hostilidades direcionadas ao político mineiro, as eleições foram realizadas e o candidato do Partido Republicano Mineiro foi declarado vencedor (CARONE, 1974a, p. 56-57).

A posse de Artur Bernardes aumentou a insatisfação política de setores do Exército vinculados ao Marechal Hermes da Fonseca, gerando contexto propício à ascensão dos tenentes como atores sociais relevantes. O movimento denominado "tenentismo" foi constituído pelas contestações capitaneadas por jovens oficiais das Forças Armadas e das Forças Públicas estaduais e representou ações de um grupo específico de militares vinculados a uma certa ideologia, dentre outras então em voga no Exército Brasileiro. Dessa maneira, as ações dos tenentes entre 1920 e 1930 não podem ser consideradas como representantes da política institucional de nenhuma das Forças Armadas (CARVALHO, 2005, p. 14; MCCANN, 2007, p. 326, 336-340).

Três grupos com três diferentes ideologias existiam dentro da força terrestre, segundo José Murilo de Carvalho (2005, p. 38-40). O primeiro defendia a ideia de

2 À época, foi atribuída ao então governador de Minas Gerais a autoria de algumas cartas cujo teor era extremamente desrespeitoso ao Marechal Hermes da Fonseca. Uma das cartas fazia alusão ao banquete promovido pelo Marechal por ocasião de sua posse na presidência do Clube Militar e continha difamações e impropérios contra o ex-presidente. O episódio das cartas falsas aumentou de modo significativo a rejeição a Artur Bernardes por parte dos jovens tenentes. Mesmo depois de descoberta a farsa e de os responsáveis por ela terem confessado a autoria, forte oposição militar à candidatura do oligarca mineiro manteve-se. 
"soldado-cidadão", em que, além das obrigações militares, todos os membros do Exército tinham o dever de exercer papel cívico ativo na esfera política. Surgida ao final do Império, essa corrente esteve vinculada aos defensores do positivismo e ganhou força na década de 1920, por meio dos ideais dos jovens tenentes rebeldes ${ }^{3}$. O argumento utilizado à época foi que a "força armada é hoje parte integrante do povo." (TÁVORA apud CARVALHO, 2005, p. 39)4 "Os tenentes pregavam uma intervenção reformista a ser feita pelo militar independente da organização, ou mesmo contra ela" (CARVALHO, 2005, p. 42).

A segunda ideologia, em oposição à primeira, defendia o distanciamento do Exército da vida política nacional como condição para uma profissionalização do militar. Conhecidos como "Jovens Turcos", os oficiais que realizaram estágio no exército alemão, entre 1906 e 1910, em sua maioria, permaneceram à margem das contestações de seus pares, durante a década de 1920. Ao contrário da corrente ideológica anterior, essa perspectiva fomentava a unidade da instituição e defendia o fortalecimento do Exército, possibilitando, dessa maneira, o surgimento de uma terceira ideologia.

Composto por algumas das características das duas vertentes apresentadas, o terceiro conjunto de ideias diferenciava-se das demais pela defesa de aspectos centralizadores. Os militares adeptos de tal posicionamento admitiam a indispensabilidade de profissionalizar o corpo do Exército e a necessidade de eventuais intervenções na vida política e social do país. Porém, entendiam que somente por meio de uma intervenção centralizada e planejada pelo alto escalão do Exército seria possível uma política da instituição Exército ao invés de várias políticas realizadas no interior dessa Força Armada. Segundo José Murilo de Carvalho (2005, p. 41-43), essa racionalidade teria o objetivo de extinguir a ideia de intervenções de cunho contestatório para dar lugar a uma intervenção controladora.

Ao não conseguir dar vazão a suas reivindicações políticas e sociais e sendo estimulados pelo debate ideológico existente no interior das Forças Armadas e pela insatisfação decorrente da situação profissional na carreira militar, os jovens tenentes passaram a contestar de modo violento a ordem vigente, por meio de rebeliões armadas, que refletiam o desejo de mudança social e política do país,

3 A vasta maioria dos oficiais participantes da Coluna Prestes agiu motivada por essa primeira ideologia. Os rebeldes opuseram-se a seus superiores e às autoridades civis da época em prol de princípios que julgavam ser de interesse nacional.

4 O principal problema da perspectiva de "soldado-cidadão" era o enfraquecimento do princípio da hierarquia dela decorrente. Se necessária, a atuação do militar poderia ocorrer mesmo em oposição a seus superiores, já que os ideais da pátria estariam acima de tudo. 
assim como alterações nas estruturas institucionais das Forças Armadas. A esse conjunto de revoltas denominou-se "tenentismo". Foi nesse contexto conturbado da década de 1920 que a Coluna Prestes teve sua origem.

\section{Os movimentos revolucionários e a formação e a marcha da Coluna Prestes}

Em 1922, durante o agitado contexto de eleições para os executivos estaduais, o então presidente Epitácio Pessoa determinou a prisão do Marechal Hermes da Fonseca após desentendimentos entre ambos. No dia seguinte, Epitácio ordenou também o fechamento do Clube Militar. Esses dois fatos serviram como estopim para a eclosão de movimentos revolucionários planejados pela jovem oficialidade, que ganharam impulso em novembro do mesmo ano, com a posse de Artur Bernardes na Presidência da República.

Em apenas dois anos, 1921 e 1922, várias conspirações ocorreram em São Paulo, Pernambuco, Rio Grande do Sul, Mato Grosso e Rio de Janeiro, no entanto, somente nos dois últimos estados houve efetiva ação rebelde, mesmo que pouco eficiente. O Levante na Escola Militar do Realengo e o Levante do Forte de Copacabana, em 5 de julho de $1922^{5}$, ambos no Rio de Janeiro, foram as primeiras de várias manifestações e ações contestatórias da década de 1920.

Em 1924, exatamente dois anos após o movimento dos Dezoito do Forte, uma sublevação liderada pelo general Isidoro Dias Lopes eclodiu em São Pauló . Após 4 dias de lutas entre as forças rebeldes e as tropas legalistas, o movimento revolucionário fez o Presidente do estado de São Paulo, Carlos de Campos, abandonar o palácio dos Campos Elíseos. No entanto, os rebeldes não puderam suportar a contraofensiva do governo. Após controlarem a capital do estado e resistirem a 23 dias de lutas e bombardeios aéreos, na madrugada do dia 28 de julho de 1924, os rebeldes abandonaram São Paulo e marcharam em direção ao oeste do estado do Paraná.

Uma das primeiras providências tomadas por Artur Bernardes, como forma de assegurar a ordem, foi decretar o estado de sítio no mesmo dia da eclosão da

5 O Levante do Forte de Copacabana deu origem ao que ficou conhecido na historiografia como os Dezoito do Forte.

6 O plano rebelde consistia em sublevar, de modo sincronizado e sem derramamento de sangue, os quartéis do Exército e da Força Pública do estado de São Paulo na madrugada do dia 5 de julho de 1924. Após controlarem a capital do estado, os revoltosos marchariam até o Rio de Janeiro, para depor o presidente Artur Bernardes e alijar do poder não somente a pessoa que consideravam inimiga do Exército, mas também todo o estamento político por ele representado: as corruptas oligarquias regionais que colocavam seus interesses privados acima dos nacionais e utilizavam o aparato institucional do Estado para auferir benefícios particulares. 
revolta em São Paulo. Com isso, o governo central obteve controle das notícias que circulavam nos maiores jornais nacionais e pôde abafar as repercussões de várias rebeliões, liberando informações somente depois de 3 a 15 dias dos eventos terem ocorrido e, mesmo assim, com forte viés pró-governo. Mesmo assim, diversas revoltas militares eclodiram por todo o país em apoio à rebelião de Isidoro Dias Lopes $^{7}$ (MEIRELLES, 1997).

Nesse contexto, um contingente de oficiais rebeldes, de vários quartéis do Rio Grande do Sul, planejou ações para sublevar-se, estabelecendo certo grau de coordenação com os militares de São Paulo, em especial com Juarez e Joaquim Távora. A atuação do capitão Luis Carlos Prestes foi fundamental para a revolta iniciar-se nessa região (PRESTES, 1997, p. 117-119; CURVO, 2005, p. 50). Apesar de todo o planejamento prévio e de terem estabelecido linhas de abastecimento que julgavam confiáveis ${ }^{8}$, os rebeldes não conseguiram manter sob seu controle a maior parte das unidades militares rebeladas no sul. Pouco depois da eclosão dos levantes nos quartéis, a atuação repressora do governo foi significativa e obrigou os revoltosos a marcharem na direção do oeste de Santa Catarina e Paraná.

Em Foz do Iguaçu, o encontro dos revolucionários paulistas e gaúchos representou o embate entre duas percepções militares diferentes. A guerra de posição clássica - ensinada pela Missão Francesa ao Exército Brasileiro e arraigada nas estratégias dos oficiais mais velhos - e a guerra de movimento - defendida por Prestes e pelos oficias que vieram com a coluna gaúcha, em função dos êxitos obtidos durante a marcha entre o Rio Grande do Sul e o oeste do Paraná. Em carta a Isidoro Dias Lopes, Prestes já havia deixado clara sua visão a respeito do Exército e do movimento rebelde à época:

A guerra no Brasil, qualquer que seja o terreno, é a guerra de movimento. Para nós revolucionários, o movimento é a vitória.

7 Como punição pelo envolvimento direto ou indireto no levante do Forte de Copacabana, o Governo Federal transferiu para organizações militares distantes vários oficiais subalternos. Ao invés de arrefecer os ímpetos dos rebeldes, essa ação ajudou a disseminar o espírito revolucionário para outros pontos do país. Aliado a esse fato, o Segundo 5 de Julho contribuiu para fazer surgir outras revoltas, solidárias aos ideais e aos propósitos dos rebeldes paulistas. Assim, sublevações de unidades militares ocorreram em Sergipe, Mato Grosso, Amazonas e Pará. Maiores detalher em Curvo, 2005; Meirelles, 1997.

8 As autoridades argentinas que haviam sido subornadas para permitir a passagem de armamentos negaram-se a cumprir com o acordado, por alguma razão. Tanto Meirelles (1997, p. 303-304) quanto Prestes (1997, p. 132) atribuem tal fato a pressões da chancelaria brasileira junto à Argentina, no sentido de cobrar do país vizinho maior vigilância do tráfego de pessoas e de bens em sua fronteira com o Brasil. Apesar de tal explicação ser verossímil, ela não pode ser estendida ao ponto de afirmar-se que o compromisso argentino com as autoridades brasileiras foi cumprido com o mesmo rigor, durante toda a campanha da Coluna, conforme analisado mais adiante. 
A guerra de reserva é a que mais convém ao governo que tem fábricas de munição, fábricas de dinheiro e bastantes analfabetos para jogar contra as nossas metralhadoras. (MOREIRA LIMA, 1979, p. 110) ${ }^{9}$

A decisão dos revolucionários de enviar à Argentina o seu comandante, o Marechal Isidoro Dias Lopes, com a finalidade de estabelecer e manter ativa rede de abastecimento bélico e de víveres, também foi tomada em Foz do Iguaçu. Com isso, esperava-se criar as condições para que o movimento rebelde pudesse perdurar e, eventualmente, triunfar ${ }^{10}$.

Do oeste do Paraná, os rebeldes atravessaram parte do território paraguaio e retornaram ao Brasil pelo Mato Grosso. A partir daí, marcharam até Goiás, subindo para o Maranhão, Piauí, Ceará. Em seguida, passaram a se direcionar para o Rio Grande do Norte, passando por Paraíba, Pernambuco e Bahia. Graças à movimentação da Coluna Prestes, o governo central e as oligarquias regionais não conseguiram deter o avanço da marcha rebelde, comprovando a eficácia da estratégia de Prestes. No entanto, a experiência pela região Nordeste fez desaparecer, nos revoltosos, a esperança de incendiar as massas populares e obter apoio a suas aspirações políticas ${ }^{11}$. Muitas adesões à Coluna ocorriam, mas as deserções também eram frequentes. Assim, durante todo o trajeto da marcha, a quantidade de integrantes oscilou entre 800 e 1400 pessoas, número muito aquém do necessário para empreender um avanço sobre o Catete.

9 Trecho de carta de Luis Carlos Prestes ao marechal Isidoro Dias Lopes, escrita em Barracão, Paraná.

10 Duas questões são passíveis de controvérsia e merecem atenção: o nome da Coluna e em que momento ela surgiu. O movimento rebelde teve como líder formal o Marechal Isidoro Dias Lopes. A marcha realizada pelo país ficou sob comando direto de Miguel Costa, mas foi marcada pela ascensão da liderança de Luis Carlos Prestes. Assim sendo, optou-se pelo nome de "Coluna Prestes" em função de esta nomenclatura ter sido escolhida por Moreira Lima, integrante da Coluna e responsável direto pela elaboração do diário de campanha dos rebeldes. Escolheu-se Foz do Iguaçu como o local de surgimento da Coluna Prestes em função do fato de que, até o encontro entre as forças paulistas e gaúchas, na cidade paranaense, o movimento revolucionário não tinha seu destino determinado. Mesmo que a intenção de Prestes, desde o início, tenha sido a de empreender uma guerra de movimento contra o governo federal, essa estratégia só foi absorvida pelo Estado-Maior revolucionário em Foz do Iguaçu. Neste local, ficou acordado que os rebeldes deveriam marchar pelo país, esperando engrossar suas fileiras para, em seguida, derrubar Artur Bernardes.

11 A dura realidade encontrada fez os jovens tenentes compreenderem que a dominação das elites sobre as camadas mais humildes da sociedade brasileira ocorria de modo muito mais intenso e complexo do que supunham. A fome e a miséria grassavam o interior brasileiro e, na maioria das vezes, a única maneira de diminuir ou amenizar os nefastos efeitos desse quadro era associar-se aos líderes locais. Assim, os rebeldes compreenderam que suas reivindicações por voto secreto, maior transparência na gestão do Estado e livre manifestação dos grupos de oposição pertenciam a uma realidade distante para as camadas populares nacionais. Antes de preocupar-se com tais aspectos da cidadania civil e política, a maior parte da população ainda se preocupava com a obtenção de meios de subsistência. 
A saída da Bahia e a entrada da Coluna em Minas Gerais ocorreu mais por necessidade que por escolha. Ao atingir o norte de Minas, o alto comando da Coluna já havia decidido emigrar para o exterior, dada as condições políticas e militares que enfrentavam. Em um primeiro momento, tal decisão só foi compartilhada entre comandantes da Coluna, nem mesmo os oficiais sabiam dela. Posteriormente, com o desenrolar da marcha, a necessidade de buscar abrigo no exterior ficou clara para todos.

Do norte de Minas Gerais, a Coluna retornou à Bahia, indo até Remanso, às margens do rio São Francisco. Em seguida, os rebeldes voltaram a Mundo Novo e cruzaram o estado até Rondelas, onde transpuseram o rio em direção a Pernambuco. Depois, entraram no Piauí e deixaram rastros na direção do Maranhão, para tentarem confundir as tropas que os perseguiam. Os rebeldes entraram em Goiás, seguiram para a região sul de Mato Grosso, retornaram a Goiás e, por fim, cruzaram a região norte de Mato Grosso até internarem-se em San Matias e Guaíba, já em território boliviano.

Em dois anos e meio de marchas, lutas e combates, a Coluna Prestes percorreu mais de 25 mil quilômetros. Ainda hoje, a distância total da Coluna continua sendo objeto de polêmica. A depender do total de quilômetros atribuídos ao movimento, esse feito pode ser considerado como a primeira ou a segunda maior marcha militar da história humana, disputa que tem como contraparte o percurso de 27.500 quilômetros feito por Alexandre, o Grande. Desse modo, não foi somente pelo fato de Luiz Carlos Prestes ter-se tornado comunista que tal empreendimento foi difundido na China, na União Soviética, na Iugoslávia e em outros países comunistas. A Grande Marcha de Mao Tsé Tung, por exemplo, foi realizada baseando-se nos feitos da guerra de movimento da Coluna Prestes e, ao contrário do movimento brasileiro, tornou-se conhecida também no mundo ocidental (SOUTO MAIOR, 2006, p. 27-47; MOREIRA LIMA, 1979, p. 497-498).

Como a Grande Marcha forneceu as bases para a vitoriosa Revolução Chinesa, seu estudo e sua difusão foram facilitados. Em contrapartida, como Prestes tornou-se comunista em 1930, incitou a Intentona Comunista em 1935 e transformou-se em inimigo do regime getulista, houve forte incentivo para que tudo vinculado ao seu nome fosse relegado a segundo plano na história do Brasil. Mesmo após a queda de Vargas, o contexto de Guerra Fria da segunda metade do século XX foi outro empecilho para a desideologização da história nacional, dificultando assim o surgimento de novas abordagens a respeito da Coluna Prestes. Isso tem sido alterado nas últimas décadas. Novos estudos a respeito da Coluna Prestes apresentam análises mais objetivas, na medida em que se abstêm 
de propagandas político-ideológicas e focam na compreensão da lógica subjacente aos acontecimentos ligados ao evento. Vale lembrar que, até 1927, Prestes ainda não havia tido contato com o pensamento marxista-leninista, tendo-se convertido a ele na Argentina, entre 1928 e 1930.

Como será visto, ao longo de todo o período em que a marcha percorreu o país, a rede de contatos entre a Coluna Prestes e os rebeldes localizados na Argentina foi sistematicamente vigiada pelo governo federal com todos os recursos de que dispunha: serviço de inteligência, informantes e redes consular e diplomática brasileira no exterior, principalmente a existente na Argentina. Além das repercussões internacionais e das perturbações domésticas, a influência da marcha rebelde na Política Externa Brasileira pode ser auferida por meio dos telegramas trocados entre a embaixada brasileira em Buenos Aires e os consulados no interior da Argentina, de um lado, e a Secretaria de Estado do Ministério das Relações Exteriores, no Rio de Janeiro, de outro.

\section{As influências da Coluna Prestes sobre a política externa brasileira para a Argentina}

\section{As políticas externas de Brasil e Argentina na década de 1920}

As relações entre Brasil e Argentina na década de 1920 foram caracterizadas por tensões. Atritos entre os dois países foram constantes nesse período e, como se verá, a Coluna Prestes foi fator que contribuiu para maior distanciamento entre os governos de Buenos Aires e Rio de Janeiro.

Embora a PEB tenha apresentado continuidade em vários aspectos, desde o início da República Velha, a atuação externa brasileira sofreu oscilações decorrentes de opções políticas e preferências diplomáticas elaboradas de acordo com necessidades de cada momento. Segundo Eugênio Vargas Garcia (2006, p. 25-26), a década de 1920 foi caracterizada por três eixos de ação da política externa brasileira: os Estados Unidos, a Europa e a América do Sul. A análise da ação externa, nesse período, deve levar em conta:

um contexto interno de crise política e institucional, prevalência do modelo agroexportador, dificuldades econômicas, dependência do capital estrangeiro e limitada capacidade estratégico-militar. Convém assinalar que a formulação e a execução da política externa estavam dominadas por pequeno círculo de elite, basicamente atores ligados ao Ministério das Relações Exteriores e a setores do governo federal. (GARCIA, 2006, p. 25) 
“Na cultura política oligárquica, a 'amizade’ pressupunha compromissos e obrigações mútuas entre os membros da comunidade. A amizade entre iguais significava aliança, a amizade entre desiguais, proteção em troca de lealdade" (GARCIA, 2006, p. 585). Enquanto o Brasil interpretava sua relação com os EUA como sendo entre iguais, os norte-americanos não recebiam o que esperavam pela proteção prestada, e esse quadro gerava dissonâncias nas relações entre os dois países. As expectativas norte-americanas de lealdade brasileira não se confirmaram, porque a política externa brasileira não se baseava em um “alinhamento automático" com os EUA, na década de 1920. A recusa do Brasil em assinar o Pacto Briand-Kellog - ou Tratado de Paris - e a decisão de não se retirar da Liga das Nações, em um primeiro momento, demonstraram tal assertiva.

Em relação à Europa, a política externa brasileira tinha como principais preocupações questões comerciais, financeiras e de status. O envolvimento do Brasil em assuntos políticos no Velho Continente buscava dotar o país de prestígio internacional. Lutando por um assento permanente no Conselho da Liga das Nações, o Brasil pareceu demonstrar não ter calculado bem seu peso na esfera internacional, à época, e acabou por gerar crise significativa no âmbito da Liga, ao vetar a entrada da Alemanha e, ato contínuo, anunciar sua retirada do Conselho e da própria Organização.

No âmbito da América do Sul, a diplomacia brasileira não se pautou por questões econômicas, uma vez que o comércio exterior do país era feito majoritariamente com os EUA e com a Europa. Nos anos de 1920, as principais preocupações do Brasil em relação à sua vizinhança passavam por aspectos estratégicos, militares e políticos. Sentindo a necessidade de modernizar e reequipar suas Forças Armadas, o Brasil buscou atuar no cenário internacional de modo a obter legitimidade para seu empreendimento. Tal fato, no entanto, foi responsável por aumentar a rivalidade com a Argentina, gerando tensões entre os dois países (GARCIA, 2006, p. 587-588) ${ }^{12}$.

Amado Cervo (1994) e José Carlos de Macedo Soares (1927) concordam que a atribulada gestão de Félix Pacheco foi uma maneira de tentar neutralizar as

12 Os efeitos dos esforços brasileiros para modernizar suas Forças Armadas foram prejudiciais à imagem externa do país. Após a I Guerra Mundial, tópicos sobre desarmamento e limitação da capacidade bélica dos países dominavam a agenda internacional. Desse modo, a diplomacia nacional trabalhou no sentido oposto ao do restante do mundo e suscitou desconfianças em sua vizinhança. Desde a chancelaria de Rio Branco, a rivalidade com a Argentina já se havia intensificado. O temor de uma "relação especial” entre Brasil e Estados Unidos e o desejo do primeiro em reequipar-se militarmente despertaram temores nos argentinos. Para mais detalhes, ver Garcia, 2006, p. 218-221; 587-588; Paradiso, 2005, p. 109-110. 
repercussões das revoltas internas, tanto na esfera internacional quanto no âmbito doméstico. Eugênio Vargas Garcia (2006, p. 491-492; 601) demonstrou como o corpo burocrático do Ministério das Relações Exteriores - MRE - foi utilizado para tentar neutralizar os efeitos e as repercussões danosos que os movimentos domésticos de contestação tiveram no exterior.

Exemplo desse fato pode ser encontrado ao analisar a marcha da Coluna Prestes. Esse movimento causou repercussão principalmente na América do Sul. As missões diplomáticas do Brasil em Assunção, Buenos Aires, Montevidéu e La Paz mandavam ao Rio de Janeiro informes e outras correspondências diplomáticas com frequência, dando ciência ao governo federal dos passos dos jovens oficiais. Dessa maneira, a política externa platina do Brasil, durante o mandato de Bernardes e início do governo de Washington Luis, empreendeu significativo esforço junto às nações vizinhas, para neutralizar o empreendimento logístico da Coluna e amenizar as más repercussões advindas do combate contra ela.

Por sua vez, na Argentina, o primeiro governo de Hipólito Yrigoyen, 1916 a 1922, e todo o mandato de Marcelo Torcuato de Alvear, 1922 a 1928, tiveram como fundamentos a luta por melhor inserção dos bens produzidos pela Argentina junto à Europa e aos Estados Unidos, demonstrando a ênfase que as autoridades do país davam à dimensão econômica da política exterior.

Se no início do século XX o principal eixo da Política Externa Brasileira já havia se deslocado da Europa para os Estados Unidos, o mesmo ainda não era verdade em relação à política externa de Buenos Aires. Na década de 1920, as relações da Argentina com a Europa continuaram sendo o centro da atuação internacional desse país. Segundo José Paradiso (2005):

Um componente central dessa trama de ligações econômicas era o fato de que a Grã-Bretanha adquiria $76 \%$ da carne argentina, sendo $54 \%$ da carne bovina congelada e $99 \%$ da resfriada. Nesses itens, em torno dos quais se articulava a coalizão de interesses econômicos mais poderosa do país - pecuaristas e empresas frigoríficas -, a subordinação argentina ao consumidor inglês e ao seu poder aquisitivo era praticamente absoluta.

Esses interesses estavam no centro da 'relação especial' com Londres por sua vez núcleo básico do 'europeísmo' econômico - e influíam nas decisões que pudessem afetá-los. Eles definiam, em última instância, as linhas principais da relação do país com o resto do mundo. (PARADISO, 2005, p. 97) 
Assim sendo, quando Artur Bernardes assumiu a presidência da República e Félix Pacheco, a pasta do Ministério das Relações Exteriores, as percepções de mundo e as prioridades que ambas as chancelarias tinham eram muito diferentes. Mesmo com a consecução do Pacto Gondra ${ }^{13}$, instrumento que conseguiu reduzir as tensões entre os países do Cone Sul, o distanciamento entre as maiores nações da América do Sul permaneceu durante a década de 1920.

Os esforços do MRE para combater a atuação da Coluna Prestes nos países vizinhos ocorreram em contexto de tensão, desconfiança e incompreensão entre Argentina e Brasil. Ao longo desse período, a Coluna Prestes forçou o Itamaraty a permanecer de prontidão para atuar junto a países vizinhos sempre que atividades rebeldes eram detectadas em territórios estrangeiros. Se a cooperação auferida pelo Brasil junto às autoridades paraguaias e uruguaias, por exemplo, foi tida como satisfatória, o mesmo não ocorreu em relação à Argentina, conforme se depreende dos telegramas trocados entre a embaixada do Brasil em Buenos Aires e a Secretaria de Estado, no Rio de Janeiro.

\section{O Itamaraty no combate à Coluna Prestes e aos movimentos que deram origem à marcha rebelde - a repercussão na política externa brasileira}

Entre os anos de 1924 e 1929, as missões do Brasil em Montevidéu, Assunção e, principalmente, Buenos Aires foram instrumentos importantes para a política externa de repressão a insurgentes, iniciada por Bernardes e continuada por Washington Luis. Assim, a questão não foi meramente pessoal, como grande parcela dos autores que escrevem sobre o tema afirma, posto que um dos objetivos declarados pelos insurgentes era a queda do governo de Artur Bernardes.

- O levantamento de informações pela rede diplomática do Brasil e as despesas extraordinárias

As críticas da Argentina à política militar e naval do Brasil pode gerar a falsa impressão de que o MRE atuou somente na defensiva durante a década de 1920 . No entanto, ao reagir perante as diferentes demandas externas, a chancelaria brasileira não descuidou do combate aos revolucionários.

13 Para maiores informações ver Garcia, 2006, p. 266-267. 
Como exemplo da atuação do serviço de inteligência do Exército Brasileiro, pode-se citar a vigilância sobre a movimentação dos rebeldes nas fronteiras do Brasil com seus vizinhos, além da atenção dada pelos militares à atuação dos servidores do Itamaraty que trabalhavam nos consulados brasileiros no exterior. Os dois casos transcritos abaixo são decorrentes do período em que a Coluna Prestes saiu de Foz do Iguaçu, cruzou parte do Paraguai e ingressou em Mato Grosso.

Para conhecimento de V. Ex. transcrevo o telegrama do Tenente Romeu Balster meu agente de informações do Rio Paraná acaba de receber Foz do Iguaçu: "Foz do Iguaçu 9/6 às 12 horas urgente Gal. Rondon Ponta Grossa. a (Conforme meu telegrama último de Posadas tem chegado da zona Mato Grosso Ponta Poran em Encarnación diversos elementos gente de Prestes creio desertores. (...) Em Encarnación pretenderam iludir boa fé nosso Consulado fazendo-se passar por emigrados Mato Grosso. Consegui em tempo reconhecê-los.) - b (Dia 31 próximo findo notei viajarem trem internacional Assunción para Argentina dois passageiros revolucionários de Prestes um negro e um menos 14 anos presumíveis. Autoridades argentinas quando comboio procede Assunción chega território argentino revistam rigorosamente e exigem passaporte. Como esses dois passageiros passaram presumo que existe alguma facilidade fornecimento de passaporte em nosso Consulado Assunción.) (...) e - (General Isidoro continuando Assunción telegrafou Simas Enéas dizendo que dinheiro todo deveria ser entregue a Miguel Costa. (...) Saudações Tte Balster.” Essa informação que é verdadeira nos mostra que Assunción e Posadas são centros atuais de onde os chefes rebeldes continuam a incentivar o bando que invadiu os sertões de Mato Grosso. (...) (AHI. Rondon a Pacheco, tel. no 2129, Ponta Grossa, 1925, Lata 46, maço 377)

Rebeldes continuam auxílios vindos da Argentina. A munição que estão empregando é reconhecida daquela origem. Seria para desejar que houvesse mais vigilância nos pontos de acessos desde Bela Vista até Pirahy. Os rebeldes viviam cruzando em livre trânsito em Bela Vista e Pedro Juan Caballero para Concepción desde muito tempo. (AHI. Rondon a Pacheco, tel. $n^{\circ} 1813$, Guarapuava, 1925, Lata 46, maço 377.)

Analisando as informações contidas nos telegramas, percebe-se que o Itamaraty estava informado em relação ao que se passava com os rebeldes. Os dados que chegavam dos consulados, da inteligência das Forças Armadas e de informantes civis criaram uma base de dados importante para o governo federal. Não se sabia das movimentações revolucionárias com profundidade; essa, inclusive, foi uma 
das razões pelas quais a Coluna Prestes conseguiu iludir as forças legalistas em diversas oportunidades, ao longo de sua marcha pelo país, mas muitas informações sobre os revolucionários - suas reais condições de combate, seus objetivos de médio prazo e seus estoques de suprimentos - eram conhecidas por Felix Pacheco e Artur Bernardes.

Como exemplo da eficiência na coleta de informações por parte do governo, pode-se citar a previsão de levante revolucionário no Rio Grande do Sul, mais tarde confirmada pela atuação de Prestes, Siqueira Campos e Juarez Távora. Há destaque para o cônsul de Posadas, que parecia estar a par de várias movimentações revolucionárias:

Dei aviso ao Presidente Borges de Medeiros desse plano dos revoltosos, que iniciarão a seção, invadindo súbita e simultaneamente o Rio Grande, por municípios de Palmeiras, São Luiz, Santo Ângelo, Bagé e Sant'Anna. João Francisco espera aviso de Tavora para vir a Posadas e seguir ao encontro de Zecca Netto e Leonel Rocha. Respeitosamente, (A) Paulo Demodoro. Cônsul. (AHI. Toledo a Pacheco, tel., n 203, 14 out. 1924, Buenos Aires, 208/03/02)

Uma das maneiras encontradas pelo governo federal para obter quantidade expressiva de dados a respeito dos rebeldes foi o pagamento de informantes, conforme se depreende do seguinte telegrama de 27 de maio de 1925:

Apurar melhor denúncia Mendes dizendo-lhe não teremos dúvida pagar-lhe os 3.500 pesos pedidos, mas depois que ele nos forneça as provas das informações que deve possuir. (AHI. Pacheco a Toledo, tel., $\mathrm{n}^{\circ}$ 82, RJ, 27 mai. 1925, 208/02/03)

Pela documentação pesquisada no Arquivo Histórico do Itamaraty, nota-se a existência de significativo número de "despesas extraordinárias" geradas pela Embaixada Brasileira em Buenos Aires e pelos consulados do Brasil em Posadas, Paso de los Libres, São Tomé e Alvear, durante o período em que a Coluna Prestes marchou pelo país. Além do atendimento a necessidades urgentes de famílias brasileiras que imigraram em busca de segurança, do reabastecimento de tropas federais e do financiamento de operações militares próximas às fronteiras, o pagamento de particulares por informações vinculadas às atividades rebeldes foi um dos principais sorvedouros das "despesas extraordinárias", sendo consideráveis as somas de recursos liberados aos postos da região platina (AHI, 208/02/03; AHI, 
208/02/04; AHI, 208/02/05; AHI, 208/02/06; AHI, 208/03/01; AHI, 208/03/02).

O pagamento de pessoas que tinham informações a respeito dos rebeldes fica também comprovado por meio de outro telegrama com o seguinte conteúdo:

Telegrama de Posadas para La Prensa dizem todas as forças rebeldes encontram-se em Foz do Iguaçu (...). Comando rebelde solicitou representante imprensa intervenham autoridades telégrafos argentino, uruguaio evitem violação despachos, dizem praticadas Libres, Santo Tomé, Caseros, Alvear, Artigas, Rivera, Mello e Rio Branco, mediante suborno pessoas interessadas. (AHI. Toledo a Pacheco, tel., $\mathrm{n}^{\circ}$ 199, Buenos Aires, 10 out, 1924, 208/02/03)

Algumas conclusões interessantes podem ser retiradas desses despachos telegráficos em destaque e de outros com conteúdo similar constantes do Arquivo Histórico do Itamaraty. Em primeiro lugar, parece não haver dúvidas de que o serviço de inteligência das Forças Armadas brasileiras atuou, de maneira estreita, com os cônsules brasileiros na Argentina, no Uruguai e no Paraguai, em contexto de articulação entre o Itamaraty e o Ministério da Guerra, tal como era de antever-se. Também, como era esperado, o pagamento por informações relacionadas à movimentação dos revolucionários foi atitude praticada pelos postos do Brasil no exterior, conforme o aumento das "despesas extraordinárias” dessas missões atesta. Surpreendente, no entanto, foi a capacidade de infiltração dos interesses brasileiros sobre os serviços de telégrafos estrangeiros ${ }^{14}$. Para obter dados sobre os rebeldes, o governo de Artur Bernardes conseguiu violar os despachos telegráficos que transitavam nas redes domésticas da Argentina e do Uruguai ${ }^{15}$.

Sabendo que os membros da Coluna Prestes combatiam a censura interna no Brasil por meio do envio de informações à imprensa argentina ${ }^{16}$, as autoridades brasileiras conseguiram subornar pessoas que trabalhavam nos telégrafos estrangeiros, para obter o conteúdo das mensagens que os rebeldes enviavam

14 De acordo com denúncias do jornal La Prensa, de 5 de dezembro de 1924, o governo brasileiro chegou a subornar funcionários de prefeituras argentinas, do sistema de transporte ferroviário e dos telégrafos com a finalidade de obter informações sobre os revolucionários. Maiores informações podem ser encontradas em AHI. Toledo a Pacheco, tel. no 386, Buenos Aires, 6 dez., 1924, 208/02/03.

15 Os dados relatados em AHI, Toledo a Pacheco, tel. nº 237, Buenos Aires, 31 out., 1924, 208/02/03, também parecem ter sido obtidos por meio de violação de despachos telegráficos.

16 Os revolucionários tinham grande facilidade de acesso aos meios de comunicação argentinos, como jornais e revistas, e deram a eles, por diversas vezes, entrevistas e declarações que incomodavam o governo federal brasileiro (AHI 208/03/02 e AHI 208/03/04). 
à imprensa estrangeira ${ }^{17}$. A existência dos dados do telegrama 199, de 10 de outubro de 1924, comprova que houve violação da correspondência dos rebeldes ${ }^{18}$.

De outra feita, conclusão interessante a respeito do comportamento dos comandados de Isidoro Dias Lopes também chama atenção. Além de combater as forças do governo federal por meio de propaganda e de ações militares, os membros da Coluna Prestes também produziram atividades de contrainteligência ao longo da marcha. Os rebeldes sabiam que o governo de Artur Bernardes havia mandado violar despachos telegráficos, subornar particulares e pagar por informações a respeito da movimentação revolucionária, e, mais uma vez, o conteúdo do telegrama 199 comprova isso, assim como outras correspondências do período. Impressiona, no entanto, o fato de que também os revolucionários tinham informantes no sistema de telégrafos do Brasil, conforme o embaixador Pedro de Toledo apurou e avisou à Secretaria de Estado, no Rio de Janeiro:

Quer dizer que os revolucionários têm no Telegrafo Nacional ou no Cabo Submarino quem lhes dê cópia dos telegramas oficiais, convindo por isso que os cônsules não transmitam por esse meio notícias que possam comprometer o movimento de tropas legais contra os rebeldes. (AHI. Toledo a Pacheco, tel., nº 403, Buenos Aires, $15 \mathrm{dez}, 1924,208 / 02 / 03$ )

Além de informantes nos telégrafos, os revolucionários tinham outros métodos para a obtenção de dados e para enganar o governo federal. Ao fazerem-se passar por emigrados, desertores ou particulares comuns, os rebeldes que se direcionavam aos consulados brasileiros no exterior buscavam recursos do governo que poderiam

17 Esses subornos parecem ter sido financiados pela mesma fonte de renda que sustentou a obtenção de informações sobre os rebeldes, ou seja, as "despesas extraordinárias” dos postos brasileiros na Argentina.

18 Há outra possibilidade para a obtenção de informações como as contidas do telegrama 199. Caso o governo brasileiro tivesse informantes infiltrados nos jornais argentinos ao invés dos telégrafos, os despacho telegráficos enviados pelos rebeldes aos periódicos platinos poderiam chegar ao conhecimento das autoridades brasileiras. Essa possibilidade parece menos crível em função de alguns aspectos. Em primeiro lugar, o governo não sabia quando e para qual jornal, ou jornais, os rebeldes enviariam mensagens - os contatos rebeldes com a imprensa argentina envolviam mais de um meio de comunicação. No entanto, o governo conhecia em quais cidades estrangeiras as atividades subversivas ocorriam. Em segundo lugar, qualquer pessoa vinculada aos diários argentinos pensaria duas vezes antes de vazar informações que pudessem prejudicar sua fonte. Além de poder perder a confiança dos revolucionários e deixar de gerar receitas com a venda de notícias, a repercussão negativa que o caso geraria poderia prejudicar a empresa que fornecesse essas informações ao Brasil. Em terceiro lugar, o serviço de inteligência rebelde e os jornais argentinos afirmaram que a violação dos despachos ocorria nas cidades de "Libres, Santo Tomé, Caseros, Alvear, Artigas, Rivera, Mello e Rio Branco, mediante suborno pessoas interessadas”, conforme o telegrama 199 deixou claro. Conferir AHI. Toledo a Pacheco, tel. nº 386, Buenos Aires, 6 dez., 1924, 208/02/03. 
ser úteis ao movimento - dinheiro por informações falsas ou vistos para faturas de exportação ${ }^{19}$-, além de tentar confundir as autoridades nacionais a respeito das operações da Coluna, por meio de informações equivocadas. É provável que sejam essas as principais razões pelas quais Pacheco chamou a atenção dos servidores no exterior para não se equivocar, "tomando rebeldes como legalistas"20, e para fornecer comprovação das “despesas extraordinárias” lançadas na contabilidade de seus postos.

O conhecimento de que o governo brasileiro estava disposto a pagar por ações ou informações que trouxessem prejuízos à Coluna Prestes não ficou restrito a pequeno grupo de pessoas. Exemplo disso é encontrado em correspondências de setembro de 1924, enviadas de Buenos Aires para o Rio de Janeiro. De acordo com o embaixador brasileiro na Argentina, um caudilho paraguaio de nome Plácido Jara procurou aquela embaixada, para desmentir o boato de que participava da Coluna Prestes e deu a entender que colocava seus serviços à disposição do governo brasileiro. Toledo desaconselhou a contratação de Jara, por considerálo perigoso e pouco confiável, mas deixou isso em aberto, para decisão final de Pacheco. Cinco dias depois, o mesmo caudilho procurou, novamente, a missão brasileira em Buenos Aires, para oferecer a organização de uma força de mil homens que viessem a combater os rebeldes, caso eles atravessassem a fronteira com o Paraguai. Novamente, Toledo desaconselhou a contratação dos serviços desse caudilho ${ }^{21}$.

Esse exemplo demonstra que, à época, na região platina, muitas pessoas sabiam que o Brasil estava disposto a pagar por todo tipo de ação ou informação que pudesse ser usada contra os rebeldes. Isso atraiu particulares que desejavam tirar proveito das verbas disponibilizadas pelo governo federal seja por meio de

19 Ao que parece, no período em análise, todo produto argentino que tivesse o mercado brasileiro como destino deveria ter suas faturas visadas no consulado brasileiro mais próximo, antes de ingressar em território nacional. O tráfico de armas é analisado mais adiante. Pelos dados do efetivo rebelde muito acima do real que foram informados às autoridades brasileiras no telegrama AHI, Toledo a Pacheco, tel. no 29, Buenos Aires, 16 jan., 1925, 208/02/04, pode-se ter ideia de como os rebeldes plantavam informações falsas nos consulados, com vistas a ludibriar o governo quanto ao seu real poder de fogo.

20 Como exemplo, podem-se citar as constantes tentativas dos rebeldes de obter vistos de exportação junto aos consulados brasileiros. Em alguns casos, equívocos foram cometidos, e os revolucionários conseguiram ter suas faturas visadas por essas repartições. Nessas ocasiões, inquéritos foram instaurados, para averiguar se houve ou não conivência dos servidores do posto, seguindo ordem da Secretaria de Estado. Conferir AHI, Pacheco a Toledo, tel., RJ, 14 out., 1924, 208/03/01.

21 Maiores detalhes podem ser encontrados em AHI, Toledo a Pacheco, tel., $\mathrm{n}^{\circ}$ 154, Buenos Aires, 24 set. 1924 , 208/02/03; AHI, Toledo a Pacheco, tel., nº 170, Buenos Aires, 29 set. 1924, 208/02/03. 
informações falsas ${ }^{22}$, seja por meio de dados fidedignos e de serviços a serem prestados. Encontram-se, na correspondência do período, relatos de que a "vigilância" sobre os rebeldes seria suspensa caso não se enviassem os recursos solicitados pelos cônsules (AHI. Toledo a Pacheco, tel. $n^{\circ}$ 55, Buenos Aires, 28 jan., 1925, 208/02/04; AHI. Toledo a Pacheco, tel. n 223, Buenos Aires, 8 mai., 1925, 208/02/04). comprovando, assim, mais uma vez, o pagamento de particulares para o constante monitoramento dos membros da Coluna.

Com vistas a coibir eventuais enganos por parte dos funcionários dos consulados e dar maior eficiência às ações de combate aos revolucionários, o Itamaraty intensificou seu controle sobre as ações dos postos do exterior. A vigilância sobre os servidores foi de tal monta que, além de punir e desautorizar quem agisse de maneira autônoma, Félix Pacheco deu instruções para Pedro de Toledo instaurar inquéritos sigilosos contra servidores que trabalhavam nos consulados brasileiros na Argentina, incluindo, no rol de investigados, os próprios cônsules. Havia o temor por parte do governo de que os rebeldes poderiam estar recebendo ajuda de funcionários consulares, conforme denúncias ocorridas à época e de acordo com relatos do serviço de inteligência das Forças Armadas (AHI. Toledo a Pacheco, tel. n ${ }^{\circ}$ 267, Buenos Aires, 5 nov., 1924, 208/02/03; AHI, Lata 46, maço 377). A Secretaria de Estado transmitiu ordem para que nenhum tipo de facilidade consular fosse disponibilizado aos revolucionários, podendo ser punido quem procedesse de maneira contrária. O controle sobre os postos na Argentina deveria ser estrito em função do objetivo do governo brasileiro de cortar a rede de abastecimento rebelde situada neste país.

\section{- O combate ao tráfico de armas pelo Itamaraty e a cooperação argentina}

Dentre os problemas gerados no âmbito internacional pelos revolucionários da Coluna Prestes, o tráfico de armas, munições e víveres foi, talvez, aquele que mais exigiu esforços por parte do Itamaraty, conforme se passa a averiguar. Pouco depois de eclodir o Segundo 5 de Julho, em São Paulo, a Secretaria de Estado já

22 A tentativa de contratar o cangaceiro Virgulino Ferreira - conhecido como Lampião - e a formação de Batalhões Patrióticos foram exemplos de disposição do governo federal em pagar particulares dispostos a combater a Coluna Prestes. O caso de Lampião, no entanto, também ilustra como o governo federal foi iludido em algumas situações. Tal parece ser a intenção de Placido Jara, segundo diagnóstico do embaixador Pedro de Toledo. O risco de perder os recursos que, eventualmente, seriam passados a esse caudilho não seria compensado pelos serviços que ele estava disposto a conceder ao Brasil. Ademais, sabendo que ele era um agitador, também se corria o risco de criar problemas com o Paraguai, caso Jara, financiado pelo Brasil, provocasse distúrbios. 
havia sido informada por Demétrio de Toledo, então cônsul em Paso de los Libres, da precária situação existente na fronteira do Brasil com a Argentina, na região compreendida entre as cidades de Uruguaiana, Paso de los Libres e adjacências - fronteira do Rio Grande do Sul com Corrientes. Em relatório de mais de 50 páginas, o cônsul expôs que o contrabando de víveres entre os dois países era algo problemático e causava grandes prejuízos ao erário nacional em razão dos impostos sobre importação e exportação que deixavam de ser arrecadados ${ }^{23}$.

Conforme o relato em questão, a situação precária da fiscalização alfandegária na fronteira entre Brasil e Argentina era bem conhecida em toda a região. Como muitos dos revolucionários eram do Sul, o mais provável é que tenham escolhido a Argentina como base logística de suas operações em decorrência da deficiência de atuação das autoridades. A relativa facilidade de escoar armas, munições e víveres através da fronteira contribuiu para que os rebeldes obtivessem recursos e criou mal-estar nas autoridades brasileiras em relação ao governo argentino.

Uma das primeiras atitudes do governo brasileiro foi enviar ordem a todas as missões da região do Prata para que tivessem rigorosa atenção em suas emissões de licenças de exportação de bens da Argentina para o Brasil. Assim, a tentativa de obter maior controle fronteiriço sobre os bens que entravam no país começou logo após o Segundo 5 de Julho, em São Paulo, conforme Félix Pacheco deixou claro por meio de telegrama emitido em 8 de julho de 1924: "autorizo consulado legalizar embarque toda e qualquer quantidade armamentos munições que governo Rio Grande do Sul importar” (AHI. Pacheco a Toledo, tel. n 31 , RJ, 8 jul., 1924, 208/03/01) ${ }^{24}$. Em outras correspondências isso também fica evidente:

Governo recomenda que consulados não permitam embarques de armas, munições e explosivos para o Brasil sem licença especial que deverá ser pedida para cada caso por intermédio deste Ministério. Rogo providenciar para exato cumprimento destas instruções. (AHI, Pacheco a Toledo, tel. n 50 , RJ, 17 set., 1924, 208/03/01)

A intenção era cortar a rede de abastecimento revolucionária localizada no exterior, dificultando as ações dos rebeldes no âmbito doméstico. Apesar de todo o esforço do governo federal, o contrabando não foi eliminado. Em julho

23 Informe do cônsul Demetrio de Toledo a Félix Pacheco, AHI, Lata 518, maço 8427.

24 Convém lembrar que tais armas poderiam ter como objetivo combater os opositores de Borges de Medeiros que haviam lutado contra ele em 1923, mas, após o Pacto de Pedras Altas, assinado em dezembro de 1923, o mais provável era que tais recursos bélicos tivessem como alvo os rebeldes de São Paulo. 
de 1925, quando a Coluna Prestes havia acabado de enfrentar forças legalistas comandadas por Bertoldo Klinger na invernada denominada Zeca Lopes, no estado de Goiás, a Secretaria de Estado retransmitiu à Embaixada brasileira em Buenos Aires telegrama com o seguinte conteúdo:

Rogo atenção de Vossa Ex. para os seguintes telegramas reservados, que acabamos de receber da fronteira:

"Os caixões de armas estavam ocultos em Garruchos e foram transportados para S.Xavier em carroças, acompanhando uma mudança simulada destinada a Caseros. O Chefe de serviço assumiu o compromisso de interceptá-la. Fidencio Mello, Leonel Rocha e Honorio Lemos desembarcaram ontem em Caseros."

"O chefe de serviço conseguiu desviar o destino de uma caixa com vinte e cinco armas Mauser, modelo 1894, vindas de S.Xavier e endereçadas ao sanatório Brasil Vianna, em Caseros, com o rótulo de material cirúrgico. Em Garruchos estão ocultos cinco caixas de armas, que Leonel Rocha e Fidencio Mello providenciam para transportá-las Caseros ou Yapeiú. As armas apreendidas pelo chefe de serviço estão ocultas em Porto Candelaria. Honório Lemos partiu na noite de vinte e sete para Estação Itapevicua, em companhia de tropeiros simulados, com destino a Concordia. À Fazenda dos Mendes, Porto de Caseros chegam diariamente grupos de seis a oito indivíduos, dizendo-se praças, mas são rebeldes vindos de S.Tomé e Libres."

Nossas forças fronteiras e autoridades uruguayas estão vigilantes para impedir qualquer passagem de armas. (AHI. Pacheco a Toledo, tel. $\mathrm{n}^{\circ}$ 90, RJ, 1 jul., 1925, 208/03/0125

No segundo semestre de 1926, já na fase final da marcha revolucionária, ocorreram apreensões de armas e munições na fronteira com a Argentina, conforme telegramas desse período evidenciam. Em correspondência de 17 de setembro de 1926, direcionada à Embaixada brasileira em Buenos Aires, por exemplo, em nome do ministro da Guerra, Félix Pacheco solicitou a Pedro de Toledo que obtivesse, junto ao governo argentino, facilidades para o livre trânsito de armas e munições apreendidas dos rebeldes na cidade de Encarnación, localidade defronte a Posadas (AHI. Pacheco a Alves, tel. n 54, RJ, 17 set., 1926, 208/03/01; AHI. Rio Branco a

25 As localidades de São Xavier e Caseros, mencionadas na mensagem, são as cidades atuais de Porto Xavier, na divisa do Rio Grande do Sul com a província argentina de Missiones e Caseiros, localizada no norte do estado gaúcho. Isso demonstra que a divisa entre Brasil e Argentina, do sul do Rio Grande até o oeste do Paraná, era região vulnerável à atividade de contrabando, na década de 1920, conforme relatório de Demétrio de Toledo. 
Mangabeira, tel. $\mathrm{n}^{0}$ 37, Buenos Aires, 15 fev., 1927, 208/02/05), comprovando a coordenação entre Itamaraty e Forças Armadas na perseguição à Coluna Prestes.

Com o intuito de combater os revolucionários, diversas gestões foram feitas junto às autoridades portenhas entre 1924 e 1927. As articulações do governo brasileiro com a Argentina envolveram pedidos a funcionários de postos policiais e alfandegários de fronteira, coordenação de ações com governadores de províncias $^{26}$, reuniões com o ministro das Relações Exteriores, Àngel Gallardo, e conferências com o presidente Marcelo T. de Alvear. Como se pode deduzir pelas correspondências constantes no Arquivo Histórico do Itamaraty, no aspecto formal, a Argentina não se furtou ao esforço de atender aos pedidos brasileiros, no entanto, no aspecto prático, as ações desse país deixaram a desejar, segundo a perspectiva de Félix Pacheco.

Tentando dar maior efetividade no combate aos rebeldes, os cônsules brasileiros foram instruídos a procurar estrita cooperação com as autoridades das províncias em que atividades de membros da Coluna eram detectadas. Foi nesse sentido que o cônsul em Posadas, Paulo Demoro, manteve conversações com os delegados da região, com o governador da província de Missiones e com o presidente do Paraná.

Transmito (...) Conversa com governador manifestei receios possibilidade vice-cônsul argentino Iguaçu ser surpreendido pedido armadores para legalizar documentos relativos cargas mercadorias embarcadas portos brasileiros e na boa fé as atender. Governador telegrafou de Aguirre a fim evitar possa realizar-se minha previsão, e que obstaria consulado embarcar aqui, medida último caso pretende usar. Sei que Rivera, República Uruguay, foram transmitidos telegramas para João Francisco, dirigidos aqui e Aguirre. Procurarei informações mais completas. Assinado Paulo Demoro, Cônsul Brasil em Posadas. (AHI. Toledo a Pacheco, tel. n ${ }^{\circ}$ 169, Buenos Aires, 29 set., 1924, 208/02/03) 27

As gestões feitas por Pedro de Toledo junto a Àngel Gallardo também merecem destaque. Após a eclosão do movimento revolucionário sob comando de Isidoro Dias Lopes, Toledo passou a pedir maior cooperação da Argentina para repreender

26 Entre 1924 e 1927, os contatos do Itamaraty com os governadores de Missiones, Corrientes e Entre Rios foram constantes. A cooperação fornecida por essas autoridades ajudou o Itamaraty a obter muitos dados sobre as atividades revolucionárias.

27 Esse telegrama, novamente, evidencia a capacidade de o governo brasileiro violar os despachos telegráficos rebeldes. Uma vez mais, os indícios apontam para interceptações na fonte das mensagens e não em seus destinos, tal como discutido anteriormente. 
as atividades dos membros da Coluna Prestes que viessem a ocorrer em seu território. Entre essas medidas, estavam incluídos maior rigor na fiscalização fronteiriça, internação de rebeldes que emigrassem para esse país vizinho, extradição de alguns brasileiros e informações a respeito de movimentações dos revolucionários:

Conversei com o ministro sobre os seguintes assuntos:

$1^{\circ}$. Contrabando na fronteira. Informei em Santo Tomé e outras partes da fronteira argentina continuava o contrabando de armas, gasolina etc para os revoltosos, segundo denunciavam nossos cônsules. Respondeu que atendendo minhas anteriores gestões havia providenciado junto às autoridades argentinas fronteiriças para evitar quanto possível esses e outros contrabandos. Hoje renovaria a expedição de ordens severas no mesmo sentido.

$2^{\circ}$. Reuniões de grupos revolucionários nas fronteiras. Também estavam dadas ordens para evitá-las, de acordo com o que antes eu havia pedido: prometia ratificá-las com energia e assegurou maior simpatia fará tudo esteja a seu alcance para auxiliar o Governo brasileiro na manutenção da ordem e restabelecimento da paz. Porém, não pode impedir que os revolucionários e legalistas atravessem desarmados o território argentino, considerando todos como simples passageiros, desde que respeitadas as leis de polícia e outras do país.

$3^{\circ}$. Firma Siqueira Campos \& Companhia. O assunto exposto não é de competência do Governo e sim do Poder Judiciário, caso os interessados reclamem contra a recusa de legalização dos documentos. O Ministro das Relações Exteriores perguntou por que o Governo brasileiro não mandava visar as faturas e não tomava depois, no Rio, providências após desembarque das mercadorias. (AHI. Toledo a Pacheco, tel., $\mathrm{n}^{\circ}$ 266, Buenos Aires, 6 nov. $1924,208 / 02 / 03)$

Pela correspondência do período, parece ter existido cooperação por parte da Argentina. É provável que a fiscalização na fronteira tenha sido melhorada tanto no lado brasileiro quanto no argentino, e a troca de informações entre as autoridades dos dois países foi prática recorrente nesse contexto de luta contra a Coluna Prestes.

Acabo de receber do Ministro das Relações Exteriores uma nota confidencial, contendo o seguinte radiograma oficial, procedente de Aguirre:

"10 de outubro, Ministro da Marinha, de bordo do Iberá-. Ausentaram-se hoje o major Rodrigues e o Tenente Perdigão, que, parece, se dirigem ao Rio 
Grande do Sul, com o objetivo de ativar os preparativos para a Revolução. Saíram também, provavelmente com mesmo destino e objetivo, Cunha Bueno e dois tenentes alemães, que estão a serviço da insurreição. Vinte e dois refugiados em 8 de outubro, mencionados no radiograma 23, embarcaram com destino a Posadas e Puerto Irigoyen. Assinado. Gallardo.”

Agradeci ao Governo argentino essa deferência. (AHI. Toledo a Pacheco, tel. $n^{\circ}$ 209, Buenos Aires, 15 out., 1924, 208/02/03)

Apesar do esforço por parte da Argentina em ajudar a combater as atividades revolucionárias que ameaçavam a ordem doméstica do Brasil, a impressão nos escalões mais altos do governo de Artur Bernardes era que Buenos Aires não estava disposta a cooperar e apresentava atitude que deixava a desejar se comparada às ações tomadas pelos governos de Assunção e Montevidéu.

Como exemplo, pode-se citar episódio em que Isidoro Dias Lopes e outros líderes rebeldes foram à Argentina, para cuidar da articulação da rede de abastecimento, em novembro de 1924. De posse de tal informação, o Itamaraty solicitou que Toledo realizasse conferência com o presidente Marcelo T. de Alvear, para transmitir-lhe tais dados e solicitar medida "enérgica e definitiva" (AHI. Pacheco a Toledo, tel. nº 69, RJ, 11 nov., 1924, 208/03/01) contra esses revolucionários. Seguindo instrução dada por Pacheco, Toledo reuniu-se com Alvear e, depois, informou ao Rio de Janeiro os resultados obtidos:

Tive hoje uma longa conferência, muito cordial, com o Presidente da República, sobre o propósito de Isidoro e João Francisco de invadir o Rio Grande do Sul. Pediu detalhes, que enviei imediatamente por memorando. Prometeu empregar todos os meios ao seu alcance para atender ao meu pedido, dentro da Constituição e dos precedentes diplomáticos. Manifestou, em termos muito honrosos, o interesse do governo argentino em concorrer e facilitar a obra desse governo para o restabelecimento da paz e concórdia na família brasileira. (AHI. Toledo a Pacheco, tel. $\mathrm{n}^{\circ}$ 311, Buenos Aires, 12 nov., 1924, 208/02/03) Destacou-se.

Poucos dias depois, Gallardo enviou notificação a Toledo a respeito das movimentações rebeldes no interior da Argentina. Segundo correspondência enviada à Embaixada brasileira em Buenos Aires, o governador de Missiones informou ao Ministério do Interior argentino, em 12 de novembro de 1924, que "os chefes revolucionários brasileiros Isidoro Dias Lopes, João Francisco (...) desembarcaram em porto caçador (...) seguindo viagem de automóvel em direção S. Tomé, Corrientes, vigiado convenientemente pela polícia do destacamento 
dessa região" (AHI. Toledo a Pacheco, tel. $\mathrm{n}^{\circ}$ 323, Buenos Aires, 14 nov., 1924, 208/02/03). Pela correspondência analisada, fica evidente que as autoridades argentinas revistaram os rebeldes brasileiros e, não tendo nenhuma razão para detêlos, liberaram seu trânsito, vigiando-os, no entanto. O pedido de uma "providência enérgica e definitiva para obstar que aqueles dois celerados prosseguissem em seu diabólico intento." (AHI. Pacheco a Toledo, tel. n 69, RJ, 11 nov., 1924, 208/03/01) não foi atendido. Como resposta a esse telegrama, Pacheco emitiu a seguinte mensagem a Pedro de Toledo:

Agradeço seu 323. A Argentina perdeu infelizmente a ocasião de fazer um gesto de boa amizade para conosco. O Memorando é uma confissão que nos penaliza. Notamos com profundo pesar o contraste dessa atitude frouxa com a solicitude das autoridades uruguaias e paraguaias de fronteira. Vossa Excelência, entretanto, não deve dar-se por achado, sem demonstrar o menor ressentimento. Temos elementos para manter a paz pública em nossa terra, ainda que a complacência das autoridades na fronteira desse país vizinho e amigo embarace e dificulte a nossa ação. (AHI. Pacheco a Toledo, tel. $n^{0}$ 71, RJ, 17 nov., 1924, 208/03/01).

A vontade do governo brasileiro era que as autoridades argentinas internassem os líderes rebeldes que estivessem atuando no território desse país, independente dos procedimentos formais que a situação demandava ${ }^{28}$. Como relatado por Toledo no telegrama $\mathrm{n}^{\circ}$ 266, de 6 de novembro de 1924, Gallardo havia deixado claro que a polícia argentina não poderia impedir a livre passagem de legalistas ou rebeldes que, desarmados, comprometessem-se a respeitar a ordem pública e as leis locais. Essa interpretação foi reforçada ainda pelo Presidente Marcelo T. de Alvear quando afirmara que tomaria todas as medidas ao seu alcance, "dentro da Constituição e dos precedentes diplomáticos”. Tal atitude foi interpretada pelo governo brasileiro como leniência e má vontade argentina em relação aos problemas brasileiros.

A irritação do Itamaraty em relação à Argentina foi constante nos anos de 1924 e $1925^{29}$. Depois de diversas gestões de Toledo junto a Gallardo e ao Presidente Alvear, o governo brasileiro não conseguiu demover as autoridades

28 Por meio do telegrama AHI. Toledo a Pacheco, tel. nº 312, Buenos Aires, 13 nov. 1924, 208/02/03, Toledo deixa claro que esse pedido foi feito durante a conferência com o Presidente Alvear.

29 A carta de reclamação do cônsul brasileiro Demetrio de Toledo ao governador de Corrientes é exemplar nesse sentido. Conferir AHI. Toledo a Pacheco, tel. n 351., Buenos Aires, 23 nov., 1924, 208/02/03. 
argentinas do respeito aos requisitos legais que a situação em questão demandava. Diante da frustração de Pacheco em ser constantemente informado sobre as ações revolucionárias em território argentino, sem poder fazer algo para impedi-las, o chanceler brasileiro orientou o embaixador em Buenos Aires a fazer uma reclamação formal perante o Ministério das Relações Exteriores desse país, quando houve, em maio de 1925, recrudescência das atividades rebeldes nas áreas próximas à fronteira:

Presidente recomenda-me telegrafar Vossa Excelência para que procure sem demora Ministro Gallardo salientando todos esses fatos e pedindo internação urgente daqueles cabecilhas e da gente que se prepara na Argentina para invadir novamente o Brasil.

Não é possível que esse governo amigo continue a recusar-nos esse pequeno serviço. V. Excelência deveria mesmo conversar depois em nota a nossa justa solicitação que é também uma reclamação. (AHI. Pacheco a Toledo, tel. nº 75, RJ, 10 mai., 1925, 208/03/01)

Quanto mais intensas eram as atividades rebeldes na fronteira, mais a atitude legalista da Argentina irritava Pacheco e Bernardes. Com vistas a conseguir que indivíduos suspeitos fossem barrados nas fronteiras de ambos os países, Pedro de Toledo chegou a tentar um acordo de cavalheiros com Gallardo, baseando-se em princípios de Direito Internacional. Circular emitida pela Secretaria de Estado orientou os consulados na Argentina a “impedir que pessoas indesejáveis ou quaisquer outras desprovidas de documentos penetrem pela fronteira, dentro de sua jurisdição, em território brasileiro” (AHI. Toledo a Pacheco, tel. $\mathrm{n}^{\mathrm{o}} 337$, Buenos Aires, 18 nov., 1924, 208/02/03). Sustentava tal diretriz a promessa de reciprocidade por parte das autoridades argentinas. Tal articulação, no entanto, não produziu os efeitos que o governo brasileiro desejava, e Pacheco chegou a afirmar que o fracasso do governo federal em derrotar os revolucionários era decorrente do fato de os rebeldes "contarem com a falta de rigor das autoridades argentinas" (AHI. Pacheco a Toledo, tel. nº 89, RJ, jun., 1925, 208/03/01).

De outro modo, apesar de os altos escalões do governo brasileiro interpretarem como lenientes as atitudes da argentina destinadas a coibir as atividades rebeldes em seu território, em março de 1927, Isidoro Dias Lopes afirmou, em entrevista a jornais argentinos, que a revolução só teria falhado por falta de apoio das autoridades vizinhas em permitir o abastecimento das forças rebeldes com armas 
e mantimentos (AHI. Rio Branco a Mangabeira, tel. n ${ }^{\circ}$ 67, Buenos Aires, 22 mar., 1927, 208/02/05). É pouco provável que qualquer meio de comunicação argentino aceitasse publicar entrevista com conteúdo que pudesse ser utilizado pelo Brasil para acusar o governo daquele país de cumplicidade com os rebeldes, mas, se não se pode afirmar que a atitude argentina foi de omissão perante os pedidos do Brasil, tampouco pode-se dizer que foi de coerção ativa, tal como desejada pelo governo brasileiro.

As razões pelas quais a Argentina não se empenhou da maneira desejada pelas autoridades brasileiras podem ser diversas. A princípio, o mal-estar gerado pelos episódios em torno do debate sobre a modernização das Forças Armadas brasileiras e o equilíbrio militar no Cone Sul, anteriores à eclosão do Segundo 5 de Julho, podem ter gerado certa indisposição no governo argentino, em relação ao problema brasileiro. Esse fator, no entanto, não serve como única explicação.

Outras duas possibilidades para a atitude legalista argentina podem ser aventadas. Em primeiro lugar, o fato de os rebeldes brasileiros comprarem produtos argentinos representava lucros para os comerciantes desse país. As compras feitas pelos membros da Coluna Prestes, ainda que não fossem extraordinárias, representaram ganhos para as economias das províncias de Missiones, Corrientes, Entre Rios e Buenos Aires. Mesmo reconhecendo que tais compras não representavam benefício significativo para a Argentina, há de salientar-se que, menos ainda, representavam prejuízos a esse país, ao ponto de demandar uma ação repressora por parte do governo portenho.

Em segundo lugar, a falta de interesse das autoridades argentinas em empenhar recursos e tempo para debelar as ações dos rebeldes em seu território pode ser decorrente do fato de que esse país não estava interessado em comprometer parcela de suas receitas com ações que iriam beneficiar diretamente o Brasil. O dispêndio de tempo e dinheiro para combater uma revolução que era exclusivamente brasileira não era visto como algo prioritário para o governo de Alvear. Na década de 1920, a Argentina tinha como diretriz de política externa os interesses econômicos dos setores produtores de carnes, trigos e outros bens primários cujo principal mercado consumidor era a Europa. Comprometer recursos do governo central de Buenos Aires na perseguição de revolucionários brasileiros que não perturbavam a ordem doméstica e, além disso, compravam produtos argentinos para enviá-los ao Brasil era fugir às prioridades estabelecidas pela chancelaria de Ángel Gallardo.

A posição legalista frente às demandas brasileiras pode ter sido a maneira encontrada de demonstrar que a Argentina colaborava, mas dentro de certos limites. 
Para Buenos Aires, esse pode ter sido o modo encontrado para não comprometer suas receitas com um problema que não lhe dizia respeito. Para o Rio de Janeiro, ficou a percepção de zelo excessivo em relação a normas e diretrizes legais que obstavam a solução de um problema grave.

Além disso, como a imprensa portenha acompanhava, de perto, todos os desdobramentos da atuação dos revolucionários da Coluna Prestes, um conjunto de ações que não respeitasse preceitos legais poderia ter má repercussão para o governo de Alvear, prejudicando sua imagem frente à opinião pública. Tal como constatado por Afrânio de Mello Franco, à época da Conferência Pan-Americana, em Santiago, a imprensa argentina foi responsável por criar tensões entre Brasil e Argentina ao longo da década de 1920, e o contexto envolvendo a Coluna Prestes não foi exceção.

Último ponto que chama atenção nos telegramas acessados no AHI foi a duração da perseguição aos revolucionários que perdurou mesmo depois do final do governo de Artur Bernardes. No mandato de Washington Luis, houve gestões para tentar uma anistia aos rebeldes, mas, como o novo presidente negou tal indulgência, houve conversações entre Brasil e Argentina para que os revolucionários obtivessem o status de asilados nesse país. Existiu a aceitação argentina nesse sentido, mas com algumas condições impostas aos rebeldes. Os insurgentes aceitaram as condições para desfrutar do asilo político, mesmo sabendo que não permaneceriam muito tempo em solo argentino. Puderam, assim, recuperar suas debilitadas saúdes e esperar pelo momento de retornar à vida pública ou militar no Brasil. Um movimento revolucionário de cunho maior estava em planejamento conforme as missões do Brasil no exterior já detectavam. De qualquer maneira, o fato de os participantes terem continuado a sofrer perseguições e intensa vigilância demonstrou que houve continuidade entre Artur Bernardes e Washington Luis na política externa de repressão aos movimentos subversivos da República Velha ${ }^{30}$.

\section{Conclusões}

De tudo exposto, percebe-se que a influência dos revolucionários da Coluna Prestes sobre a atuação externa do Brasil foi significativa entre julho de 1924 e março de 1927. O combate aos movimentos sediciosos do período, a busca

30 Para maiores informações sobre essa continuidade, conferir as correspondências constantes em AHI 208/02/05; AHI 208/02/06; AHI Lata 46, maço 378. 
por neutralizar as notícias que eram direcionadas ao exterior e a tentativa de cooperação com os países da vizinhança foram constantes. Os esforços do Itamaraty foram recompensados por meio da ajuda recebida das autoridades das nações vizinhas, ainda que Pacheco tenha considerado o empenho da Argentina como algo comedido.

O contexto foi caracterizado por momentos de tensão e mal-estar nas relações entre Rio de Janeiro e Buenos Aires. Quando Gallardo assumiu a chancelaria argentina, a situação entre os dois governos já se encontrava deteriorada, e as desconfianças mútuas permaneceram ao longo da década de 1920. Pouco depois da posse de Gallardo no Ministério das Relações Exteriores argentino, ocorreu a eclosão do Segundo 5 de Julho em São Paulo. Dessa data até o fim da marcha revolucionária, em março de 1927, o Brasil utilizou-se de seus postos consulares e de sua Embaixada na Argentina para demandar junto a Alvear ajuda no combate aos revolucionários que tinham o território desse país como base de operações logísticas para sua rede de abastecimento.

A cooperação argentina foi realizada de modo constante, mas não da maneira desejada pelo Itamaraty. Bernardes e Pacheco queriam que Buenos Aires efetivasse a prisão, a internação ou qualquer outra medida contra os rebeldes que colocasse fim a suas atividades na região platina. Apesar de Pacheco ter obtido informações sobre os revolucionários, o governo brasileiro não conseguiu impedilos de continuar atuando na Argentina, em decorrência do respeito de Buenos Aires a diretrizes legais, o que irritou, profundamente, o Itamaraty e o presidente Bernardes. Para o MRE, os argentinos usavam preceitos legais para disfarçar sua má vontade em lidar com o caso, o que, como visto, pode não ser totalmente desprovido de verdade.

Com o levante dos membros da Coluna Prestes, as relações com Buenos Aires ganharam importância para o Brasil. O uso do Ministério das Relações Exteriores como instrumento de repressão foi importante estratégia do governo brasileiro no combate aos rebeldes. O suborno a empregados dos telégrafos e de outros órgãos dos países vizinhos, o pagamento por informações vinculadas aos revolucionários e a atuação dos cônsules junto às alfândegas do Brasil e dos outros países da região platina demonstram como o Itamaraty tentou cercar a atuação dos membros da Coluna. Ademais, o trabalho em conjunto entre o Itamaraty e o Ministério da Guerra pode ter ajudado os comandantes militares que combateram a Coluna Prestes a melhor conhecer a situação dos revolucionários. Ressalte-se, no entanto, que o conhecimento dessas informações pode ter sido importante, 
mas não foi decisivo para as operações do governo, já que as tropas legalistas não conseguiram derrotar os rebeldes. ${ }^{31}$

Nos anos de 1927 e 1928, a vigilância dos postos brasileiros nos Estados platinos possibilitou ao governo federal saber que algo estava para ocorrer. Um movimento maior do que o produzido pela Coluna Prestes estaria na ordem do dia, segundo alguns relatórios enviados pelos cônsules brasileiros em Posadas, Paso de los Libres, Corrientes, Missiones e Iguazu. Até que ponto tal preocupação era somente uma especulação decorrente do receio que tais funcionários tinham e até que ponto esse fato conseguiu predizer a Revolução de 1930 é algo que os telegramas não permitem concluir. Certo é, no entanto, que, de acordo com vários autores, Prestes foi convidado a liderar militarmente o movimento contra Washington Luis, quando ele ainda estava na região platina. Assim sendo, as conversações preliminares entre rebeldes ilustres, como Siqueira Campos, Juarez Távora e Luis Carlos Prestes, com os organizadores da Revolução de 1930 podem ter sido, em algum grau, captadas pelas autoridades brasileiras entre 1928 e 1930, por meio do que Eugênio Vargas Garcia (2006, p. 491) denominou “diplomacia antirrevolução das oligarquias". Demonstrando como o eficiente aparato montado para combater a Coluna Prestes continuou a funcionar mesmo após o fim do movimento.

\section{Referências}

\section{ARQUIVO HISTÓRICO DO ITAMARATY - AHI}

AHI. Pacheco a Toledo, tel. no 31, RJ, 8 jul., 1924, 208/03/01.

AHI, Pacheco a Toledo, tel. no 50, RJ, 17 set., 1924, 208/03/01.

AHI, Toledo a Pacheco, tel., n ${ }^{\circ}$ 154, Buenos Aires, 24 set. 1924, 208/02/03.

AHI. Toledo a Pacheco, tel. $n^{\circ}$ 169, Buenos Aires, 29 set., 1924, 208/02/03.

AHI, Toledo a Pacheco, tel., $\mathrm{n}^{\circ}$ 170, Buenos Aires, 29 set. 1924, 208/02/03

AHI. Toledo a Pacheco, tel., n ${ }^{\circ}$ 199, Buenos Aires, 10 out, 1924, 208/02/03.

AHI, Pacheco a Toledo, tel., RJ, 14 out., 1924, 208/03/01.

31 Os telegramas AHI. Toledo a Pacheco, tel. no 173, Buenos Aires, 16 abr., 1925, 208/02/04 e AHI. Toledo a Pacheco, tel. $\mathrm{n}^{\circ}$ 192, Buenos Aires, 24 abr., 1925, 208/02/04, demonstram que o governo federal previu a possibilidade de os rebeldes, acuados no oeste do Paraná, abrirem caminho pelo Paraguai, para atingir o Mato Grosso. Como Rondon foi surpreendido por essa manobra, abre-se espaço para indagações a respeito de como os dados levantados pelo Itamaraty eram utilizados pelo Ministério da Guerra e vice-versa, já que ambos os órgãos trabalharam em estreita cooperação no combate aos revolucionários. 
AHI. Toledo a Pacheco, tel., no 203, 14 out. 1924, Buenos Aires, 208/03/02. AHI. Toledo a Pacheco, tel. no 209, Buenos Aires, 15 out., 1924, 208/02/03. AHI, Toledo a Pacheco, tel. no 237, Buenos Aires, 31 out., 1924, 208/02/03. AHI. Toledo a Pacheco, tel. n 267, Buenos Aires, 5 nov., 1924, 208/02/03. AHI. Toledo a Pacheco, tel., nº 266, Buenos Aires, 6 nov. 1924, 208/02/03. AHI. Pacheco a Toledo, tel. $n^{\circ}$ 69, RJ, 11 nov., 1924, 208/03/01.

AHI. Toledo a Pacheco, tel. n 311, Buenos Aires, 12 nov., 1924, 208/02/03. AHI. Toledo a Pacheco, tel. no 312, Buenos Aires, 13 nov. 1924, 208/02/03. AHI. Toledo a Pacheco, tel. n 323, Buenos Aires, 14 nov., 1924, 208/02/03. AHI. Pacheco a Toledo, tel. nº 71, RJ, 17 nov., 1924, 208/03/01.

AHI. Toledo a Pacheco, tel. $n^{\circ}$ 337, Buenos Aires, 18 nov., 1924, 208/02/03. AHI. Toledo a Pacheco, tel. no 351, Buenos Aires, 23 nov., 1924, 208/02/03. AHI. Toledo a Pacheco, tel. $n^{\circ}$ 386, Buenos Aires, 6 dez., 1924, 208/02/03. AHI. Toledo a Pacheco, tel., no 403, Buenos Aires, 15 dez, 1924, 208/02/03. AHI, Toledo a Pacheco, tel. no 29, Buenos Aires, 16 jan., 1925, 208/02/04. AHI. Toledo a Pacheco, tel. no 55, Buenos Aires, 28 jan., 1925, 208/02/04. AHI. Toledo a Pacheco, tel. $\mathrm{n}^{\circ}$ 173, Buenos Aires, 16 abr., 1925, 208/02/04. AHI. Toledo a Pacheco, tel. no 192, Buenos Aires, 24 abr., 1925, 208/02/04. AHI. Toledo a Pacheco, tel. n 223, Buenos Aires, 8 mai., 1925, 208/02/04. AHI. Pacheco a Toledo, tel. $\mathrm{n}^{\circ}$ 75, RJ, 10 mai., 1925, 208/03/01. AHI. Pacheco a Toledo, tel., nº 82, RJ, 27 mai. 1925, 208/02/03. AHI. Pacheco a Toledo, tel. nº 89, RJ, jun., 1925, 208/03/01. AHI. Pacheco a Toledo, tel. no 90, RJ, 1 jul.,1925, 208/03/01. AHI. Rondon a Pacheco, tel. n 2129, Ponta Grossa, 1925, Lata 46, maço 377. AHI. Rondon a Pacheco, tel. no 1813, Guarapuava, 1925, AHI Lata 46, maço 377. AHI. Pacheco a Alves, tel. ${ }^{\circ}$ 54, RJ, 17 set., 1926, 208/03/01.

AHI. Rio Branco a Mangabeira, tel. no 37, Buenos Aires, 15 fev., 1927, 208/02/05. AHI. Rio Branco a Mangabeira, tel. nº 67, Buenos Aires, 22 mar., 1927, 208/02/05. AHI. Lata 46, maço 377.

AHI. Lata 46, maço 378.

AHI. Lata 518, maço 8427.

AHI. Maços 208/02/03; 208/02/04; 208/02/05; 208/02/06; 208/03/01; 208/03/02; 208/03/04.

CARONE, Edgard. A Primeira República: 1889-1930. $2^{\text {a }}$ ed. São Paulo: DIFEL, 1974a. CARVALHO, José Murilo. Forças armadas e política no Brasil. Rio de Janeiro: Jorge Zahar, 2005. 
CERVO, Amado Luiz; BUENO, Clodoaldo. História da Política Exterior do Brasil. Brasília: Editora Universidade de Brasília, 1994.

CURVO, Luiz Márcio Ambrósio. Jovens, tenentes e rebeldes: a liderança da Coluna Miguel Costa - Prestes. 2005. 139f. Dissertação (Mestrado em História) - Departamento de História do Instituto Ciências Humanas da Universidade de Brasília, Brasília.

GARCIA, Eugênio Vargas. Entre a América e a Europa: A política externa brasileira na década de 20. Brasília: Editora Universidade de Brasília/FUNAG (Fundação Alexandre de Gusmão), 2006.

MCCANN, Frank D. Soldados da pátria. A história do Exército Brasileiro - 1889/1937. Rio de Janeiro: Cia das Letras, 2007.

MEIRELLES, Domingos. As noites das grandes fogueiras: uma história da Coluna Prestes. Rio de Janeiro: Record, 1997.

MENDONÇA, Sônia Regina. A consolidação da República oligárquica. In LINHARES, Maria Yedda (org). História geral do Brasil. 9' ${ }^{a}$ ed. Rio de Janeiro: Elsevier, 1990, pp. 320-321.

MOREIRA LIMA, Lourenço. A coluna Prestes. Marchas e combates. São Paulo. Editora Alfa Ômega. 1979.

PARADISO, José. Um lugar no mundo: a Argentina e a busca de identidade internacional. Rio de Janeiro: Civilização Brasileira, 2005.

PRESTES, Anita Leocádia. A coluna Prestes. Rio de Janeiro: Paz e Terra, 1997.

RAPOPORT, Mario (org.). Historia econômica, política y social de la Argentina. (1880-2000). $2^{\text {a }}$ Ed. Buenos Aires: Ediciones Macchi, 2003.

SOARES, José Carlos de Macedo. O Brasil e a Sociedade das Nações. Paris: A Pedone, 1927. SOUTO MAIOR, Laércio. Luiz Carlos Prestes na Poesia. Curitiba: Travessa dos Editores, 2006.

Nota: Em função das especificidades envolvidas na pesquisa no Arquivo Histórico do Itamaraty, os mesmos documentos citados pordem ser referenciados da seguinte maneira: Escritório Regional do Ministério das Relações Exteriores no Rio de Janeiro.

\section{Correspondências:}

- Missão diplomática brasileira em Buenos Aires Telegramas Recebidos: 1924 (208/2/3), 1925-1926 (208/2/4), 1927 (208/2/5), 1928-1929 (208/2/6).

Telegramas Expedidos: 1921-1926 (208/3/1), 1927-1929 (208/2/6). 
- Missão diplomática brasileira em Montevidéu Ofícios: $1922(223 / 3 / 1)$

- Missão diplomática brasileira em Assunção Telegramas Recebidos: 1917-1926 (202/2/1)

- Outros documentos relacionados, separados por organização temática: Lata 46, maço 377

Lata 183, maço 3039

Lata 471, maço 7203

Lata 478, maço 7453

Lata 518, maço 8427 